\title{
SUGGESSTED MODEL FOR MONITORING AND CONTROL OF FOODBORNE PATHOGENS IN WILD BOAR'S MEAT
}

\author{
Jelena Petrović ${ }^{11^{*}}$, Jovan Mirčeta ${ }^{2}$, Dragan Antićs \\ Ivan Pušić ${ }^{1}$, Miroslav Urošević ${ }^{4}$ \\ ${ }^{1}$ Scientific veterinary Institute „Novi Sad“, Novi Sad \\ ${ }^{2}$ Veterinary Station, Bačka Palanka \\ ${ }^{3}$ Faculty of Agriculture, Department of Veterinary, Novi Sad \\ ${ }^{4}$ Institute for reproduction and artificial insemination, Temerin
}

\section{Abstract}

Wild animal meat harvesting and processing is significantly different from classical livestock meat production and represents a challenge by itseIf. Implementation of concept "from forest to fork" encompasses influence of hunting ground ecology, type of hunting, field evisceration of hunted game, meat inspection after shooting or transport etc. The objective of this paper was to propose a model for monitoring and control of food born pathogens in wild boar's meat. Hazard analysis emphasized the importance of several pathogens: Mycobacterium spp., Salmonella spp., Trichinella $s p p$., and a five-step control program were proposed. The program includes management of microbial contamination of wild boar meat, control measures for live animals, control measures during hunting and after shooting, guidelines for official meat inspection with specific details for control of identified hazardous pathogens and control measures for wild boar carcasses processing. The research on presence of food born pathogens in wild boar meat is still scarce, while the Trichinella spp. live cycle is well described and there are relevant data about epidemiology and natural reservoirs of the parasite in this part of Europe, little is known about tuberculosis and salmonellosis prevalence in wild boar population. Thus, implementation

\footnotetext{
${ }^{{ }^{*}} \mathrm{dr}$ sci vet med Jelena Petrović, viši naučnet aladnik Naučni institu za veterinarstvo Novi Sad

${ }^{2} \mathrm{mr}$ sci vet med Jovan Mirčeta, veterinarska stanica Bačka Palanka

${ }^{3}$ doc dr sci vet med Dragan Antić, Poljoprivredni fakultet Novi Sad, Departman za veterinu $\mathrm{mr}$ sci vet med Ivan Pušić, istraživač saradnik Naučni institu za veterinarstvo Novi Sad ${ }^{4} \mathrm{dr}$ sci vet med Miroslav Urošević, naučnet aladnik Naučni institu za reprodukciju i veštačko osemenjavanje Temerin
} 
of control program, with strictly defined control measures cannot be overemphasized, and should include veterinary officials as well as hunters and others involved in game meat chain.

Key words: meat, wild boar, control program, food borne pathogens

\title{
PREDLOG MODELA PRAĆENJA I KONTROLE ALIMENTARNIH PATOGENA U MESU DIVLJIH SVINJA
}

\author{
Jelena Petrović ${ }^{1}$, Jovan Mirčeta², Dragan Antić3 \\ Ivan Pušić ${ }^{1}$, Miroslav Urošević ${ }^{4}$ \\ ${ }^{1}$ Naučni institut za veterinarstvo „Novi Sad“, Novi Sad \\ ${ }^{2}$ Veterinarska stanica, Bačka Palanka \\ ${ }^{3}$ Poljoprivredni fakultet, Novi Sad \\ ${ }^{4}$ Naučni institu za reprodukciju i veštačko osemenjavanje Temerin
}

\section{Kratak sadržaj}

Lanac proizvodnje mesa divljači se umnogome razlikuje od klasične proizvodnje mesa domaćih životinja i predstavlja jedinstven izazov. Primena koncepta „od šume do trpeze“ obuhvata uticaj ekosistema lovišta, lova, evisceracije na zemlji, pregleda nakon klanja, transporta itd. Osnovni cilj ovog rada je predlog programa praćenja i kontrole anlimentarnih patogena u mesu divljih svinja. Identifikacijom hazarda izdvojeni su sledeći patogeni: Mycobacterium spp., Salmonella spp., Trichinella spp i predložen je program kontrole koji obuhvata: opcije za kontrolu mikrobiološke kontaminacije mesa divlje svinje, kontrolne mere kod živih divljih svinja, kontrolne mere tokom lova i odstrela, opis službene kontrola odstreljene divljači sa specifičnostima za kontrolu identifikovanih hazarda i kontrolne mere tokom obrade trupova divljih svinja. Prisustvo alimentarnih patogena u mesu divljih svinja još uvek je relativno neistražena oblast. Dok o Trichinella spp postoje relevantni podaci i poznat je način održavanja životnog ciklusa ovog parazita na našim prostorima o prevalenci tuberkuloze i salmoneloze malo se zna. Stoga je primena ovakvog programa sa jasno definisanim merama kontrole više nego svrsishodna. Dobro je poznata činjenica da lica koja rukuju sa izlovljenom divljači imaju malo ili nikakvo znanje o osnovnim higijenskim principima. Primena programa za kontrolu alimentarnih patogena treba da uključi kako lica u lovištima tako i veterinare koji vrše službenu kontrolu.

Ključne reči: meso, divlje svinje, program kontrole, alimentarni patogeni 


\section{INTRODUCTION}

Game disease control includes the control of disease spread from wildlife reservoirs to domestic animals, as well as control of zoonotic emerging infectious diseases that represent a significant threat to public health. The possibility of disrupting ecological balance in wildlife population is of special concern in the implementation of wild animal disease control measures. It is widely accepted that complete eradication of shared infectious agents is almost impossible in wildlife hosts serving as natural reservoirs of human and livestock infections.

Harvesting and processing of wild game meat is substantially different from classical livestock meat production and represents a challenge by itself. Implementation of the concept "from forest to fork" encompasses the influence of hunting ground ecology, type of hunting, field evisceration of hunted game, meat inspection after shooting or transport etc. The risk assessment of food borne pathogens in wild boar addresses the following two main items: defining epidemiological differences between wild animals and livestock and the criteria for food safety assessment to be followed for game meat.

Domestic animals raised for food production in farm conditions undergo regular veterinary health control as well as ante and post mortem inspection at slaughterhouses, while in game species; only post mortem examination is widely practiced.

Official criteria for game meat risk assessment are still lacking, and are hard to be established because average daily game meat varies significantly in different regions. Consumption of game meat is limited in general population, but some specific groups consume significant amounts. Game meat consumption in hunter families in EU is estimated at $4 \mathrm{~kg} /$ year (Ramanzin et al., 2010).

The objective of this paper was to propose a model for monitoring and control of food borne pathogens in wild boar meat. The program includes management of microbial contamination of wild boar meat, control measures for live animals, control measures during hunting and after shooting, guidelines for official meat inspection with specific details for control of three selected hazardous pathogens and control measures in the processing of wild boar carcasses.

\section{HAZARD IDENTIFICATION}

Two criteria were established in wild boar meat hazard identification: evidence of spread of hazardous pathogens during handling, processing and con- 
sumption of wild boar meat and evidence of presence of shared pathogens in wild boar population in specific geographical region. Hazard analysis emphasized the importance of three pathogens:

- Mycobacterium spp. (bacterial agent that infects animals; sometimes without clinical manifestations, transmitted to humans via contact with infected carcass or raw meat and products)

- Salmonella spp. (zoonotic bacterial agent, naturally occurs in animal's digestive organs, contaminates carcasses in abdominal shots or during inadequately performed evisceration);

- Trichinella spp. (parasitic agent, humans typically acquire the infection by consuming raw or undercooked meat infested with infectious Trichinella larva)

\section{Mycobacterium bovis}

Mycobacterium spp. represents the major biohazard in large game. In the South Bačka region (SBR), three hotspots of endemic bovine tuberculosis (BTB) were identified, in the municipalities of Žabalj, Titel and Novi Sad. The prevalence of infected cattle in affected herds varied from $11.10 \%$ to $59.18 \%$ (Pusic et al., 2009). Data on BTB presence in wild boar population in the same area are lacking, and a field research is in progress.

Infection of humans with M. bovis may occur by inhalation of aerosols or through consumption of milk or at some extent meat contaminated with the bacilli.

There is evidence for human infection through wild boar meat consumption (Ashford et al., 2001).

The most important natural reservoir species for maintaining BTB in Europe's wildlife population are badger (Meles meles), wild boar (Sus scrofa) and deer belonging to subfamily Cervinae. Wild boars can serve as a reservoir of infection for domestic animals but may also be of public health significance as a direct source of human infection (Gortazari et al, 2008). Epizootical investigations considering BTB in Vojvodina province revealed that there are tuberculous districts in South Backa region with a high incidence of BTB positive animals and herds (Pusic et al., 2007; Pusic et al ., 2013).

Serbian BTB eradication program is based on regular annual bovine intradermal tuberculin testing, compulsory slaughter of positive animals coupled with frequent skin testing in infected and incontact herds, movement restrictions, meat inspection at abattoirs and computer based evidence (Pusic et al., 2008; Pusic et al., 2009a,b,c). Implementation of similar surveillance and eradication programs in wild animal populations is quite impossible to achieve. 


\section{Trichinella spp}

Trichinellosis is widespread in most of Europe. In Serbia, the endemic regions for trichinellosis are Srem, the valleys of Danube, Drina and Kolubara (Petrovic et al., 2012a). Investigation of trichinella outbreaks in Vojvodina province during the period 2002-2011, revealed that eating of raw, poorly processed or undercooked meat and products from backyard domestic pigs was a main source of human infection (Urosevic et al., 2013). Wild boar to human transmission of live trichinella larvae through meat consumption are well documented in Serbia (Urosevic et al., 2013). In Europe, wildlife represents the most important reservoir of Trichinella, which makes eradication impossible and explains why the parasite continue to circulate, even though the prevalence in wildlife can be very low for many years (Rafter et al., 2005).

Research on trichinellosis carried out by Petrovic et al. (2012a,b,c) in Vojvodina region revealed high prevalence of infection in jackals (8.33\%), foxes (5\%), and at less extent wild boars (1\%). In some European countries, where eradication of trichinellosis in domestic animals is accomplished (like Denmark), the prevalence of sylvatic trichinellosis is extremely low (0.001\%) (Enemark et al., 2000). The parasitic burden in omnivorous and carnivorous game in Vojvodina region is higher (3 larvae/10g) if compared to countries with no trichinellosis registered in domestic animals (e.g. Denmark 1 larva/10 g). The infestation is particularly high in wild boars in Vojvodina, reaching even 1.100 larvae/g (Petrovic et al., 2013a). High incidence of sylvatic trichinellosis in a particular geographic area poses substantial risk of infection spread to domestic pigs, especially in the grazing habitat (Petrović et al., 2013a,b). In pigs, trichinellosis is usually contracted through cannibalism, ingestion of synantropic and sylvatic animals, or feces of animals in early stages of infection (1-2 post infection) (Petrovic et al., 2014).

\section{Salmonella spp.}

Salmonella spp infection in wild boar population is traditionally associated with S. typhimurium, but in recent decades, the range of serotypes isolated from carcasses, tonsils, feces and lymph nodes is much broader. Large differences in the prevalence of different Salmonella spp. serotypes are not only reported among species (for example, it is higher in wild boar than in ruminants), but also between particular regions (i.e., higher prevalence was established in the southern states of the EU) (Table 1). 
Table 1. The prevalence of Salmonella spp. in wild boar in different European countries (Paulsen et al., 2011)

\begin{tabular}{|c|c|c|c|}
\hline Animal species/sample & Country & $\begin{array}{c}\text { No. sam- } \\
\text { ples }\end{array}$ & Positive samples \\
\hline \multirow{2}{*}{ Wild boar/feces } & Italy & 2365 & $441(18.7 \%)$ \\
\cline { 2 - 4 } & Portugal & 77 & $17(22.1 \%)$ \\
\cline { 2 - 4 } & Switzerland & 73 & $4(5.5 \%)$ \\
\hline
\end{tabular}

In Serbia, the researches on game pathogens conducted so far were predominantly focused on wild birds and enteropathogens other than Salmonella spp. (Stojanov et al., 2012; Velhner et al., 2012). The prevalence of Salmonella spp. in carcasses of wild boar is relatively low, less than $10 \%$ (unpublished data), but the infection in wild boar is much more common as compared to wild ruminants. Therefore, inadequate evisceration and/or direct bullet shot through abdominal cavity increase the risk of Salmonella spp. contamination of the meat of wild boar (Wisniewski, 2001).

\section{CONTROL OPTIONS FOR MICROBIOLOGICAL CONTAMINATION OF WILD BOAR MEAT}

According to recommendations of Codex Alimentarius Commission (CAC, 2005), the control is focused on hygiene and game meat inspection in the primary stages of the meat chain (including transport), as the important measures for the control of the meat of hunted game. The recommendations have been implemented in national legislation of countries of Central Europe (Regulations (EC) No 853/2004 and 854/2004).

The control measures are divided into two groups:

(1) visual inspection for the presence of disease and assessment of all major changes (clearly visible pathological changes, severe contamination from the environment or in case of suspected specific biohazard, additional laboratory testing is recommended)

(2) implementation of practical skills and knowledge aiming to prevent dissemination and multiplication of food borne pathogens (i.e. Salmonella $s p p$.) on/in edible tissues. 


\section{CONTROL MEASURES}

\section{Control measures in wild boar population}

Control of zoonotic agents in wild animal population could be attempted through vaccination campaigns, by keeping animals in isolated geographical areas or fenced hunting grounds to prevent contact with domestic animals and wild animal additional feed ban (Zanella et al. 2008).

Wild animal population size regulation (managing overabundance) contributes in infectious disease control by decreasing transmission rate. When field evisceration is performed, offals and other remains should be removed from hunting ground to disrupt transmission chain of food born pathogens, especially tuberculosis and trichinellosis (Gortazar et al., 2006; Petrović et al., 2012a). Wild boars are at a greater risk of contracting tuberculosis compared to deer, as a result of a hunting management policy (Vincente et al., 2006). The main risk factor is artificial additional nutrition of wild pigs to preserve the high density of population, which enhances hunting opportunities but also facilitates the transmission of infectious diseases (Vincent et al., 2007). Scavenging habits of wild boars and eating offals of deer that have succumbed to the disease or were killed sanitary increases the risk for tuberculosis, salmonellosis and trichinellosis (Gortazer et al., 2008).

According to Petrović et al. (2014), life cycle of T. spiralis in Vojvodina region includes circulation from domestic pigs to wild boars and vice versa, which is associated with characteristic behavior of this animal species. Wild boars are very tolerant to the presence of humans, often commingling with domestic pigs on common pastures, and have access to laystall and food waste. Improper disposal of pig carcasses and offals in the field represents the greatest risk factor for trichinellosis maintenance and spread in pig population.

In actual scientific literature, there are no published recommendations (at least to our knowledge) on Salmonella spp. control measures in live wild boars. Therefore, it is important to control the hygiene during hunting, evisceration, bleeding and cleaning of carcasses, cooling and transportation, coupled with sampling of processed carcasses and testing for the presence of Salmonella spp.

\section{Control measures during hunting and shooting}

Good hunting practice should be implemented as observation prior shooting "ante mortem" inspection, that includes observation of the behavior of the living animal, constitution and presence of suspect alterations that may be indicative for infective or parasitic disease (coughing, diarrhea, abnormal movements or position of limbs, rough hair etc.). The stress that animal suffers 
prior killing may be acute or protracted, and is largely dependent to a hunting method. Prolonged stress and the number, position and caliber of the entry wounds have a great influence on the microbiological condition of the carcass, causing invasion of bacteria from digestive tract or insertion of bacteria and dirt with the bullet itself. During hunting, a risk of animal's muscle glycogen storage depletion is increased, resulting in an increase in $\mathrm{pH}$ levels in the meat, which negatively affects the quality and microbiological status of meat (Wiklund and Smulders, 2011). Hunter's skill and experience, as well as the used bullet and its caliber greatly influence the game meat quality (Atanassova et al., 2008).

\section{Official game meat inspection}

Official meat inspection, immediately after shooting, is carried out by an authorized veterinarian or veterinary inspector in a depot for cooling and temporary storage of game carcasses (Urošević et al., 2012a).

Hunting manager provides information about hunting process and all relevant details to veterinary official. These include data of carcass marking, information on abnormalities in behavior or health status of animals prior shooting, and potential alterations in organs and carcass after evisceration (Urosevic et al., 2012b).

The evisceration in large game has to take place as soon as possible after killing, especially the stomach and bowels. All the eviscerated organs must be kept until the veterinary inspection is completed. Skinning and cutting up game is not allowed in field conditions.

Veterinary inspection of meat and viscera of hunted wild boars must identify:

- any abnormalities or alterations that may indicate that the meat presents a health risk for humans or other animals;

- presence of any sign of disease or condition that makes meat unsuitable or forbidden to be put on the market;

- any autolytic alterations due to delayed evisceration or other reasons;

- any alterations related to consumption of toxic substances;

Meat and viscera of hunted animals are visually inspected, and palpation or incision is performed if needed. Considering that several hot spots of endemic bovine tuberculosis are registered in Vojvodina region, palpation and incision of hepatic lymph nodes should be performed. If any suspicion remains, laboratory testing is recommended (Urosevic et al., 2014). 
The diaphragms of all killed wild boars must be examined by pepsin digestion method for estimating the presence of Trichinella spp larvae.

The wild boar meat deriving from animal infected with salmonellosis, tuberculosis or trichinellosis is declared unsuitable for human consumption. Standard game meat inspection is effective for identifying and elimination of altered and visually contaminated carcasses, but ineffective in detection of subclinical salmonella carriers (Petrovic et al., 2013b).

\section{Control measures during carcass processing}

After killing and evisceration, the carcass and matching viscera have to be transported as soon as possible to a game collection facility for inspection, marking and assessment. Quick cooling down is essential for food safety and meat quality, thus, if the environmental temperature is high it is necessary to chill the game meat within a reasonable period of time and no later than 10 hours after killing. This should result in a temperature throughout the meat of not more than $+7^{\circ} \mathrm{C}$.

To the purpose of veterinary inspection of meat, Paulsen et al. (2006) categorized the carcasses according to contamination of body cavities and other alterations (such as emaciation, fractures, discoloration) into four categories, with two best categories (i.e., not requiring veterinary intervention) characterized by TVC $<6 \log \mathrm{cfu} / \mathrm{cm}^{2}$ (colony forming units) and $E$. coli counts $<1$ $\log \mathrm{cfu} / \mathrm{cm}^{2}$. It is important to emphasize, that the time passed from killing to cooling should be as short as possible, because high ambiental temperature is strongly associated with microbial growth and meat contamination, and a period of maximum 12 hours of "pre cooling" is suggested (Paulsen and Winkelmayer, 2004). According to Regulation (EC) 853/2004, the recommended temperature for chilled game meat should be $+7^{\circ} \mathrm{C}$ and for the offals maximum of $+3{ }^{\circ} \mathrm{C}$. For skin removal and subsequent carcass processing, in terms of cross-contamination, similar procedures apply as for cattle (Paulsen et al., 2011).

\section{CONCLUSION}

The research on presence of food borne pathogens in wild boar meat is still scarce, and lack sufficient data. The presence of alimentary pathogens in wild pigs' meat is relatively unexplored research area. While the Trichinella spp. life cycle is well described and there are relevant data about epidemiology and natural reservoirs of the parasite in this part of Europe, little is known about tuberculosis and salmonellosis prevalence in wild boar population. Thus, implementation of control program, with strictly defined control measures cannot 
be overemphasized, and should include veterinary officials as well as hunters and others involved in game meat chain.

\section{ACKNOWLEDGEMENT}

This work was supported by the Ministry of Science and Technological Development of the Republic of Serbia, grants TR 31084.

\section{REFERENCES}

1. Ashford D.A., Whitney E., Raghunathan P., Cosivi O.: Epidemiology of selected mycobacteria that infect humans and other animals. Rev Sci Tech. 20, 1, 325-337, 2001

2. Atanassova V., Apelt J., Reich F., Klein G.: Microbiological quality of freshly shot game in Germany. Meat Science, 78, 4, 414-419, 2008

3. CAC Codex alimentarius CAC/RCP58-2005. Code of hygienic practice for meat

4. Enemark H., Bjorn H., Henriksen S., Nielsen B.. Screening for infection of Trichinella in red fox (Vulpes vulpes) in Denmark. Vet Parasitology 88, 3-4, 229-37, 2000

5. Gortazar C, Acevedo P, Ruiz-Fons F, Vicente J. Disease risks and overabundance of game species. European Journal of Wildlife Research 52, 8187,2006

6. Gortazar C, Torres J, Vicente J, Acevedo P, Reglero M, de la Fuente J, Negro JJ, Aznar-Martin J.: Bovine tuberculosis in Doñana Biosphere Reserve: the role of wild ungulates as disease reservoirs in the last Iberian lynx strongholds. PLoS One. Jul 23,3,7:e2776, 2008. doi: 10.1371/journal. pone.0002776.

7. Paulsen P i Winkelmaye: Sesonal variations in bacterial contamination of game carcasses in Austria. Eur J Wildl Res 50, 157-159, 2004

8. Paulsen P, Schopf E, Smulders F.: Enumeration of total aerobic bacteria and E. coli in minced meat and on carcass surface samples with an automated most-probable-number method compared to colony count protocols. Journal of food protection 69, 10, 2500-20503, 2006

9. Paulsen, P., Smulders, F.J.M. \& Hilbert, F.: Salmonella in meat from hunted game: A Central European perspective. Food Research International, 45, 609-616, 2012

10. Petrović J., Pušić I., Apić J., Milanov D., Grgić Ž., Đorđević V., MatekaloSverak V.: Silvatična trihineloza - uloga divljih životinja u ciklusu širenja trihineloze u Srbiji. Veterinarski glasnik, 66, 3-4, 175-183, 2012a 
11. Petrović J., Pušić I., Milanov D., Urošević M., Stojanov I., Grgić Ž.: Role of the jackal in sylvatic trichinellosis in Serbia. In: Second International epizootiology Symposium XIV Serbian epizootiology days, 18-21.04.2012, Pp 157-162, 2012b

12. Petrović J., Pušić I., Urošević M.: Sylvatic trichinosis in the area of Vojvodina. In: Game Meat Hygiene in Focus, 11-12.10.2012. Vienna, Proceedings Pp 61, 2012c

13. Petrović J., Pušić I., Stojanović D.: Silvatična trihineloza na području Vojvodine. [urednik Dragan Rogožarski], U: Zbornik radova 10. Simpozijuma 'Zdravstvena zaštita, selekcija i reprodukcija svinja', Srebrno jezero, 31.05-02.06.2012., Pp 114-114, 2012d

14. Petrović J., Grgić Ž., Živkov-Baloš M.: Molecular diagnostics of trichinella species: new data on trichinella life cycle in Vojvodina region. In: Proceedings, Conference Meat and Meat Products - Perspectives of Sustainable Production, 10-12.06.2013, Belgrade, Proceedings Pp 153-158, 2013a

15. Petrović J., Došen R., Grgić Ž., Stojanov I., Milanov D.: Značaj salmoneloze u primarnoj proizvodnji svinja i uticaj na bezbednost mesa. U: 11.Simpozijum sa međunarodnim učešćem Zdravstvena zaštita, selekcija i reprodukcija svinja. Pp 98-98, 2013b

16. Petrović J., Grgic Z., Pusic I., Urosevic M.: Sylvatic trichinosis in the Vojvodina region (Serbia). In: Trends in game meat hygiene- From forest to fork. Wageningen Academic Publishers, AE Wageningen, The Netherlands, Pp175-181, 2014

17. Pušić I., Đuričić B., Bugarski D., Prodanov J., Santrač V.: Epizootiološke karakteristike tuberkuloze goveda u koviljskom ritu. U: IX epizootiološki dani sa međunarodnim učešćem, 28-31.03.2007. Požarevac Pp 135-137, 2007a

18. Pušić I., Đuričić B., Savić-Jevđenić S., Prodanov J., Bugarski D., Grgić Ž., Milićević V.: Vrednovanje i primena mycobacterium bovis gama interferon testa u dijagnostici tuberkuloze goveda. U: X epizootiološki dani, 2-5.04.2008. Tara , p 207-208, 2008

19. Pušić I., Đuričić B., Milićević V., Grgić Ž., Prodanov J., Bugarski D.: Metode dijagnostike tuberkuloze na živim govedima. U: 8. kongres veterinara Srbije, Veterinarska medicina, život i zdravlje, 15-19.09.2009. Beograd, 101-102, 2009a

20. Pušić I., Lalošević D., Bugarski D., Prodanov J., Grgić Ž., Urošević M., Lupulović D.: Epizootiološke karakteristike tuberkuloze goveda u Južnobačkom okrugu. Arhiv veterinarske medicine, 2, 55-63, 2009b

21. Pušić I., Milićević V., Savić S., Prodanov J., Grgić Ž., Bugarski D., Stojanov I.: A preliminary trial to evaluate the gamma-interferon assay for the de- 
tection of tuberculosis in cattle under local conditions in Serbia. LUCRARI stiintifice, 125-130, 2009c

22. Pušić I., Prodanov-Radulović J., Ratajac R., Stojanov I., Urošević M., Marčić D.: The use of different diagnostic techniques in cattle tuberculosis eradication. In: Proceedings, II International Symposium and XVIII Scientific Conference of Agronomists of Republic of Srpska 26-29.03.2013, 372-373, 2013

23. Rafter P., Marucci G., Brangan P., Pozzio E.: Rediscovery of Trhichinella spiralis in red foxes (Vulpes vulpes) in Ireland after thirty years of oblivion. J. Infect. 50, 61-5, 2005

24. Stojanov I., Kapetanov M., Živkov-Baloš M., Petrović J., Potkonjak D.: Ecological role of bacterial isolates in protected wild birds. In: Proceedings International symposium on hunting, 22-24.06.2012, Pp 107-109, 2012

25. Ramanzin M, Amici A, Casoli $C$ et al.: Meat from wild ungulates: ensuring quality and hygiene of an increasing resource. It $J$ of Anim Sci. 9:e61doi:10.4081/ijas.2010.e61, 2010

26. Regulations (EC) 853/2004 i 854/2004

27. Urošević M., Aleksić Z., Petrović J., Pušić I., Radović I., Stojanac N.: Swine trichinellosis in Serbia - legislation in relation to the European Union. In: Proceedings Second International epizootiology Symposium. XIV Serbian epizootiology days, 18-21. 04.2012, 149-156, 2012a

28. Urošević M., Paulsen P., Petrović J., Ristić Z., Jajić I.: The importance of trichinellosis and other zoonoses of the wildlife in the West-Balkan region. In: Proceedings International symposium on hunting 22-24.05.2012, 113$117,2012 b$

29. Urošević M., Petrović J., Mirilović M., Risatić Z., Jajić I.: Karakteristike trihineloze kod ljudi na teritoriji Vojvodine u periodu 2002-2011. Arhiv veterinarske medicine $6,1,45-55,2013$,

30. Urosevic I.M., Ristic A.Z.: Veterinary and sanitary examination of game meat in the West-Balkan region - harmonization with European. In: Trends in game meat hygiene - From forest to fork. Wageningen Academic Publishers, AE Wageningen, The Netherlands, 281-289, 2014

31. Vicente J, Hofle U, Garrido JM, Fernandez-de-Mera IG, Juste R, Barral $\mathrm{M}$, Gortazar C. Wild boar and red deer display high prevalences of tuberculosis-like lesions in Spain. Veterinary Research 37, 107-119, 2006,

32. Vicente J, Hofle U, Garrido JM, Fernandez-de-Mera I G, Acevedo P, Juste $\mathrm{R}$, Barral M, Gortazar C .: Risk factors associated with the prevalence of tuberculosis-like lesions in fenced wild boar and red deer in south central Spain. Veterinary Research 38, 451-464, 2007

33. Velhner M., Suvajdžić L., Petrović J., Šeperanda M.: Antimicrobial resi- 
stance of escherichia coli in wild animals. Arhiv veterinarske medicine, 5 , $35-44,2012$

34. Wiklund i Smulders. Muscle biological and biochemical ramifications of farmed game husbandry with focus on deer and reindeer. In: P. Paulsen, A. Bauer, M. Vodansky, R. Winkelmayer, and F.J.M. Smulders, editors, Game meat hygiene in focus. Microbiology, epidemiology, risk analysis and quality. Wageningen Academic Publishers, 297-311, 2011.

35. Wisniewski J.: The incidence of Salmonella spp. in wild boars in Poland. Medycyna Weterynaryjna, 57, 399-401, 2001

36. Zanella G, Durand B, Hars J, Moutou F, Garin-Bastuji B, Duvauchelle A, Ferme M, Karoui C, Boschiroli M. :Mycobacterium bovis in wildlife in France. Journal of Wildlife Diseases, 44, 99-108, 2008

Primljeno: 15.11.2014.

Odobreno: 20.11.2014. 